\title{
人工降雨装置を用いた土壤の浸食量と 粒径分布に関する実験的検討 EXPERIMENTAL STUDY ON AMOUNT OF SOIL EROSION AND PARTICLE SIZE DISTRIBUTION BY USING RAINFALL SIMULATOR
}

\author{
新谷惠 $1 \cdot$ 木内豪 2 ・小俣哲平 3 \\ Megumi ARAYA, Tsuyoshi KINOUCHI and Teppei OMATA \\ 1学生会員 工修 東京工業大学大学院 総合理工学研究科 環境理工学創造専攻 \\ （†226-8503 神奈川県横浜市緑区長津田町4259） \\ 2正会員 工博 東京工業大学大学院教授 総合理工学研究科 環境理工学創造専攻 \\ （テ226-8503 神奈川県横浜市緑区長津田町4259） \\ 3正会員 工修 大成建設株式会社技術センター（†245-0051 神奈川県横浜市戸塚区名瀬町344-1）
}

\begin{abstract}
The radioactive substance, such as ${ }^{134} \mathrm{Cs}$ and ${ }^{137} \mathrm{Cs}$ from the Fukushima Dai-ichi Nuclear Power Plant (FDNPP), were transported with finer soil particles. In order to simulate the radiocesium transport, it is necessary to understand well the behavior of soil particle in hydrological systems. In this paper, we conducted the soil erosion experiment by using rainfall simulator and applied the existing erosion model to experimental results. Then we focused on the soil erosion phenomenon of each soil particle size. According to the experimental result, erosion rate reduces with time and flow rate become constant. The particle size distribution of eroded sediment and original soil surface are similar results. The existing erosion model reasonably reproduced different characteristic of each soil type and each particle size.
\end{abstract}

Key Words : Soil erosion, Rainfall simulator, Sediment transport, Particle size distribution

\section{1.はじめに}

2011年に発生した福島第一原子力発電所の事故により 環境中に放出された放射性物質は大気中に拡散したのち, 風雨によって陸域にも拡散した．放射性物質の中でも放 射性セシウム137は半減期が30年と長く, 一度放出され てしまうと環境中に長くとどまり，移行していく．この 陸域における放射性物質污染の移行過程について, さま ざまな機関により研究が行われ，実態解明が進められて いる1).

陸域から水系へ移行する放射性物質の主な供給源は, 陸域表層に存在する土粒子等の放射性セシウムを吸着し た物質である.とりわけより小さな懸濁性の微細粒子

(数 $\mu \mathrm{m}$ 数 $10 \mu \mathrm{m} の$ 範囲) がより多く放射性物質を吸着 することが示唆されている2).このような微細粒子の発 生源となる土褰表面からの侵食や表面流出の研究はこれ までもなされているが，流出土砂の粒径を考慮した現象 理解やモデル化が不十分であり, 総量としてのモデル化 にとどまっている3). 人工降雨装置を用いて土䁃侵食現
象を理解する取り組みとして，海外では砂と粘土を人工 的に混合した土壌を用いた実験344)自然の土壌を用い た実験5が行われているが，いずれも粒径については着 目していない，また，国内でも自然の土壌を用いて土壌 クラストの形成と浸食量の関連性を検討した実験(は行 われているが，海外同様に粒径別に侵食現象を整理され た研究は少ない. しかし，放射性物質吸着量の粒径依存 性に鑑みると，流域スケールでのより精度の高い放射性 物質の移行解析と長期的な動態予測を行っていくために は，現地の土壤を対象に流出土砂の粒径分布を考慮した 侵食現象の理解やモデル化がさらに必要である.

そこで，新たに作成した人工降雨装置と現地の不擾乱 土壌を用いた土壌侵食実験を行い，流出土砂量の総量の みならず，土粒子粒径も考慮した土壌侵食現象の理解と 既存モデルとの比較・検討を行った.

\section{2. 研究対象地域と土袞採取地の概要}

福島県の中心を流れる阿武隈川流域の支川である移川 


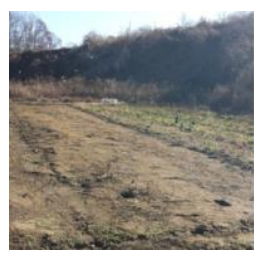

たばこ畑

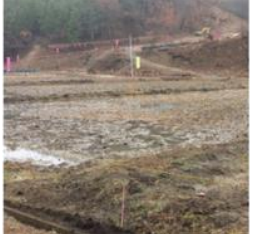

水田

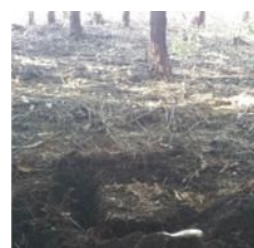

森林
図-1土壌採取地の写真

流域内の口太川を研究対象地域とした。本川は福島県西 白川郡西郷村旭岳に水源を発し，福島県内を北上し宮城 県に入り太平洋へと流れ込む一級河川である. 口太川流 域は阿武隈川水系の中央東側に位置しており，流域面積 は約 $138 \mathrm{~km}^{2}$ である。土地利用は，国土交通省のデータ より，農地が $29 \% ，$ 森林が55\%，水田が11\%を占めてい る.

本研究では，口太川上流の山木屋地区から土袞を採取 し，実験に用いた。土壌採取地の写真を図-1に示す。た ばこ畑は採取時には耕作されていない場所である．水田 は除染作業前の土壊表面が人工的に乱されていない場所 から採取した．森林はスギ林内の土袞を採取した。

\section{3． 実験装置と実験方法}

\section{（1）室内人工降雨装置}

本実験では，噴射角約 $70^{\circ}$ のフルコーン型のスプ レーノズル（霧のいけうち，1/4 M J 070M BW）4本を 用いた．スプレーノズルだけでは，与えたい降雨強度で 雨滴径，雨滴落下速度，降雨分布の均一性を自然に近い 状態に保てないため, 園芸用のポータブルブロワーバ キューム（RYOBI，PSV-600）を設置し，ノズルから噴 出される水滴に上方から強風を当てることで飛散させ, 自然に近い均一性と雨滴径を実現した。実験装置の概要 図を図-2に示す，ノズルを設置した高さは土壤表面から 約 $3.5 \mathrm{~m}$ である. 水の供給は, 実験室の一般的な水道の 蛇口からホースを用いて直接ノズルへ接続するかたちで 行った. また, 供給される水の水圧が雨滴径と均一性に 影響するため, 常に一定の水量を供給できるように水圧 計（長野計器, JIS汎用形圧力計 A 枠 GS50-1710.1MP）で実験中の水圧を監視した。雨滴径と雨滴落下 速度はディスドロメーター（ThiesCLIMA，Laser Precipitation Monitor 5.4110.00.100）を用いて計測した. 降雨強度と均一性は縦横 $30 \mathrm{~cm}$ で深さ $10 \mathrm{~cm}$ の容器を, 縦 横 $5 \mathrm{~cm}$ の36マスに仕切った測定用のマスを製作し，10分 間人工降雨中に置くことで計測した。降雨強度と均一性 は，測定用マスの中心部分16マスを用いて計算し，確認 した。この人工降雨装置では約 $110 \mathrm{~mm} / \mathrm{h} \sim 130 \mathrm{~mm} / \mathrm{h}$ の降 雨強度を発生させることができ，10分間測定した降雨分 布の均一性の各マスの標準偏差は1.0〜 2.0 mm/10min と なった，また，雨滴径は主に $1 \mathrm{~mm} \sim 3 \mathrm{~mm}$ 程度で，最大

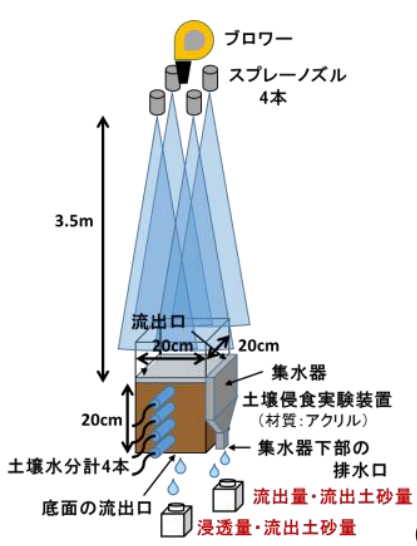

図-2＼cjkstart実験装置の概概要図

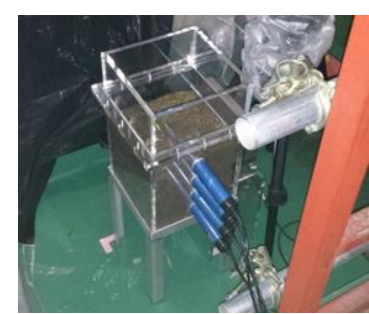

(a) 土㙵容器全体

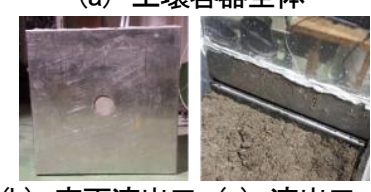

（c）流出口

\section{表-1 採取土壤の概要}

\begin{tabular}{|c|c|c|c|}
\hline サンプル名 & 採取日 & 採取深度 & 採取地点の勾配 \\
\hline たばこ畑(1) & $2014 / 12 / 3$ & $0-20 \mathrm{~cm}$ & 緩勾配 \\
\hline たばこ畑(2) & $2015 / 1 / 18$ & $15-35 \mathrm{~cm}$ & 緩勾配 \\
\hline 水田 & $2014 / 11 / 27$ & $0-20 \mathrm{~cm}$ & なし \\
\hline 森林 & $2014 / 11 / 22$ & $0-20 \mathrm{~cm}$ & 急勾配 \\
\hline
\end{tabular}

$8 \mathrm{~mm}$ 程度の大きさも観測された．今回の実験に用いた 人工降雨は，観測された雨滴径分布と落下速度を用いて 雨滴の運動エネルギーフラックスを計算すると, 自然降 雨の降雨強度 $30 \mathrm{~mm} / \mathrm{h} \sim 40 \mathrm{~mm} / \mathrm{h}$ 程度の持つエネルギーと 等しい結果となった。

\section{(2) 土壤の採取}

現地から不擾乱の土壌を採取して実験に用いるため, 土壌採取後から実験まで土壤を入れ替える必要がないア クリル製の容器（図-3(a)）を製作し，土壌採取を行っ た。採取する土壤の大きさは $20 \mathrm{~cm}$ 角とした. Heilig ${ }^{3)}$ が $7 \mathrm{~cm}$ 角の人工的に砂と粘土を混合した土壌で土壌侵食 実験を行っており，Mahmoodabadiら5)はイラン中央部の 実際の土壌を用いて実験を行っているが，本実験では， 福島県の現地から採取した不擾乱土袞を用いた.

採取した土壤の採取日、採取深度、採取地点の勾配を 表-1に示す。勾配のある地点では, 土㙥容器の流出口側 に斜面下方がくるように採取した。土壤表面の土粒子粒 径は，後述の図-5(a)に示すような粒径分布であり，た ばこ畑は砂質が多く，水田は粘土質が多く，森林は有機 物の多い一般的な森林土壌であった。

\section{（3）土袞侵食実験装置}

現地から採取してきた $20 \mathrm{~cm}$ 角の不擾乱土壌が入った 容器に, 図-2の土壌容器の側面に描いているような表面 流出を集める集水器などのアタッチメントをつけること でそのまま実験に用いることができる実験装置を製作し た（図-3）．湛水深を変えられるように，集水器の流出 口の高さを調節できるようにした．流出口のスリット

（図-3 (c)）から越流した水は，集水器下部の排水口か 
表-2＼cjkstart実験の測定項目と使用機器

\begin{tabular}{|c|c|c|}
\hline \multicolumn{3}{|c|}{ 実験前 } \\
\hline 測定項目 & 使用機器 & 測定時間 \\
\hline 雨滴径 & \multirow{3}{*}{ ディスドロメーター } & \multirow{3}{*}{ 30分間 } \\
\hline 雨滴落下速度 & & \\
\hline 雨滴の粒径分布 & & \\
\hline 降雨の均一性 & \multirow{2}{*}{ 測定用のマス } & \multirow{2}{*}{ 10分間 } \\
\hline 降雨強度 & & \\
\hline \multicolumn{3}{|c|}{ 実験中（連続6時間） } \\
\hline 流出量 & \multirow{3}{*}{$\begin{array}{c}\text { サンプリング用ボトル } \\
(500 \mathrm{ml})\end{array}$} & \multirow{3}{*}{ 15分間 } \\
\hline 流出土砂量 & & \\
\hline 浸透量 & & \\
\hline 土壌表面の状況 & タイムラプスカメラ & 10秒ごと \\
\hline \multicolumn{3}{|c|}{ 実験後 } \\
\hline 降雨強度 & 測定用のマス & 10分間 \\
\hline 土粒子粒径分布 & 粒度分布測定装置 & \\
\hline SS濃度 & 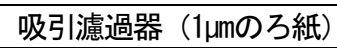 & \\
\hline
\end{tabular}

表-3 土壊侵食実験の実験条件

\begin{tabular}{|c|c|c|c|c|}
\hline サンプル名 & 回数 & 湛水深 & 降雨強度 & 浸透流出 \\
\hline \multirow{2}{*}{ たばこ畑1 } & 1回目 & $7 \mathrm{~mm}$ & $120 \mathrm{~mm} / \mathrm{h}$ & 有 \\
\cline { 1 - 5 } & 2回目 & $10 \mathrm{~mm}$ & $114 \mathrm{~mm} / \mathrm{h}$ & 無 \\
\hline \multirow{2}{*}{ たばこ畑(2) } & 1回目 & $3 \mathrm{~mm}$ & $111 \mathrm{~mm} / \mathrm{h}$ & 有 \\
\hline \multirow{2}{*}{ 水田 } & 1回目 & $3 \mathrm{~mm}$ & $118 \mathrm{~mm} / \mathrm{h}$ & 有 \\
\cline { 2 - 5 } & 2回目 & $20 \mathrm{~mm}$ & $124 \mathrm{~mm} / \mathrm{h}$ & 無 \\
\hline \multirow{2}{*}{ 森林 } & 1回目 & $4 \mathrm{~mm}$ & $132 \mathrm{~mm} / \mathrm{h}$ & 有 \\
\cline { 2 - 5 } & 2回目 & $3 \mathrm{~mm}$ & $121 \mathrm{~mm} / \mathrm{h}$ & 有 \\
\hline
\end{tabular}

ら排出され，500mlのボトルで回収できるようになって いる.

容器側面の一つには土壊水分計 (ICT International, SMM土壌水分メーターMP306 Moisture Sensor）を土䁃 表面からの深度 $2.5 \mathrm{~cm}, 7.0 \mathrm{~cm}, 11.5 \mathrm{~cm}, 16.0 \mathrm{~cm}$ に4本差 し込めるようになっており，実験中の土壌内の水分変化 を確認できるようになっている，ステンレス製の底蓋に は中心に直径 $2 \mathrm{~cm}$ の穴が開いており，ステンレスフィル ター（マツバラ金網株式会社，目の開き $132 \mu \mathrm{m}$, 線径 $80 \mu \mathrm{m} ， 120$ メッシュ， $\phi 50 \mathrm{~mm} ）$ を通して土堙を浸透し た水が流れでて来るようになっており（図-3(b)），表 面流出と同様に $500 \mathrm{ml}$ ボトルで回収する，ステンレス フィルターによって土壤の底面が崩れ出ることを防いで おり，湛水させる条件ではこの穴をふさぐことができる ようにしている.

また，本実験では，傾斜の影響を除いた状態で，雨滴 の衝撃力と湛水深の影響による浸食現象のそれぞれの土 褰の特性を調べるため，土壌容器には傾斜を付けず，土 壌表面が水平な状態で実験を行った。

\section{（4）実験手順}

土壤侵食実験における測定項目，使用機器，測定時間 を表-2に示す。まず，土壌侵食実験を行う前に人工降雨 の準備・測定を行う。降雨装置の雨滴径や均一性は水を 供給後すぐは安定しないため, 安定するまで20～30分通
水し，安定したら30分間ディスドロメーターで雨滴径と 雨滴落下速度を計測する。その後，前述の測定用のマス で10分間，降雨強度と均一性を確認した上で，土壌侵食 実験装置を設置し，実験を開始する，表面流出は連続15 分間ごと，浸透流は連続30分ごとに500mlのボトルに回 収する。

6時間の実験後，再度，降雨強度と均一性が実験前と 変わりがないか，測定用のマスで測定し，確認した．湛 水深については実験前と実験後に土壤表面9か所で土壤 表面の高さを計測しておき，実験中30分ごとに土壤容器 側面から数枚撮った写真から湛水面を読夕取って求めた. 回収したサンプルの分析については，表面流は15分間ご とのサンプルを $1 \mu \mathrm{m}$ のガラス繊維フィルター（Whatman, ガラス繊維ろ紙，孔径 $1 \mu \mathrm{m} ， \phi 47 \mathrm{~mm})$ を用いて一部ろ 過し，SS濃度を測定し，SS濃度と流出した水の総量か らSSの総量（流出土砂量）を求めた.

15分間ごとにある流出サンプルから15分目から30分刻 みでサンプルを抜粋し，レーザー回折式粒度分布測定装 置（島津製作所，SALD-3000）を用いて，SSの粒度分 布を測定した．表面流出サンプルに大きな有機物がある 場合には，サンプルのろ過と粒度分布測定をする前に一 度 $2 \mathrm{~mm}$ の目のふるいを通して，2mm以上の物質を取り 除いた.

\section{4. 実験結果 · 考察}

\section{（1）実験条件}

現地から採取したたばこ畑土壤2体（たばこ畑(1)，た ばこ畑(2)），水田土壌，森林土壤の計4体の土畩サンプ ルを用いて実験を行った。それぞれのサンプルでの湛水 深，降雨強度，底面からの浸透流出の有無を表-3にまと める．実験の継続時間は6時間で，森林の2回目のみ実験 継続時間を4時間とした．湛水深は流出量が安定する1時 間目以降の湛水状況を撮影した写真から実際に読み取っ た值を載せている．また，水田の湛水 $20 \mathrm{~mm}$ の条件を除 き，実験開始時は土壌表面が湛水していない状況から開 始した．水田 $20 \mathrm{~mm}$ は湛水してから越流してくるまで時 間を要するので，あらかじめ湛水させた状態から実験を 開始した。

\section{（2）流出量 - SS濃度 - 流出土砂量 · 浸透量の結果}

土畩表面から流出してきた水の総量である流出量, サ ンプルをろ過して測定したSS濃度と流出量を乗じて求 めたSSの量である流出土砂量, 底面からの流出を測定 した浸透量の実験結果を図-4に示す。流出量については, 降雨開始時は土壌が乾いているため，初めの30分程度は 降雨が土壌に浸透していきやすく，流出量が低くなって いるが，水田の湛水20mm以外は1時間以内に安定する 結果となった（図-4(1)，(2)，(3)）。図-4(2)の水田の湛 


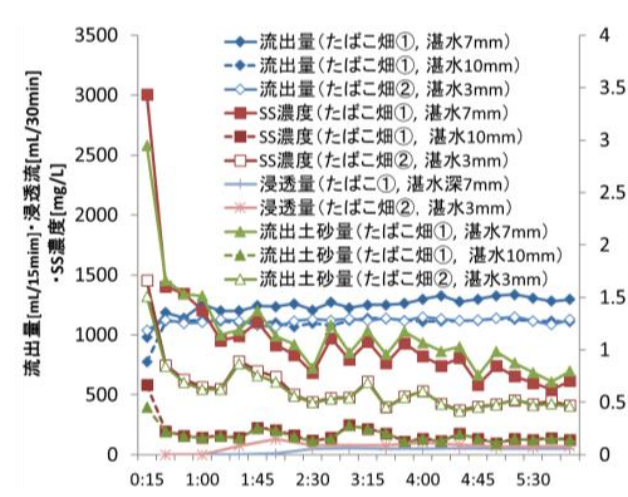

（1） たばこ畑(1)・たばこ畑(2)

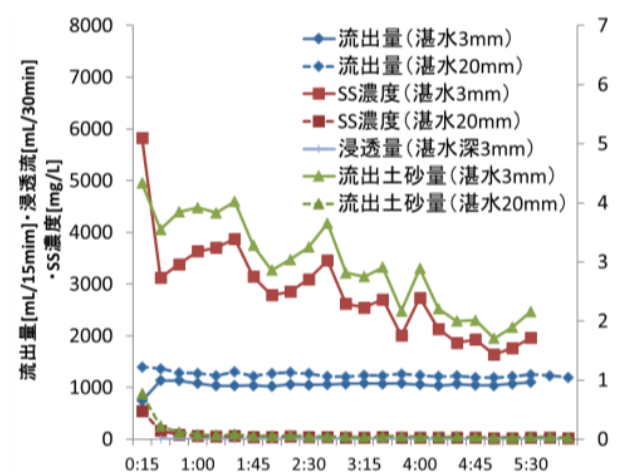

（2） 水田

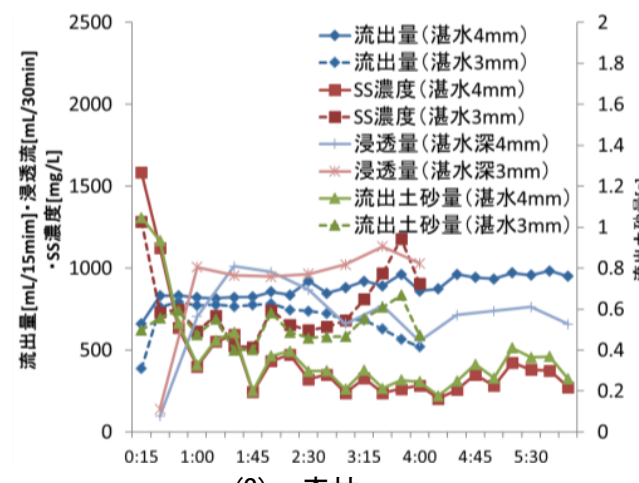

(3) 森林

図-4 流出量 · SS濃度 · 流出土砂量 $\cdot$ 浸透量

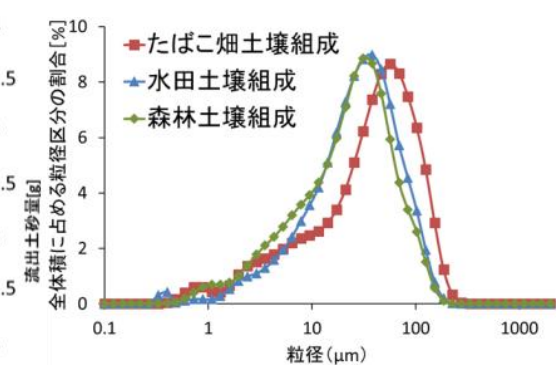

(a) 各表面土袞
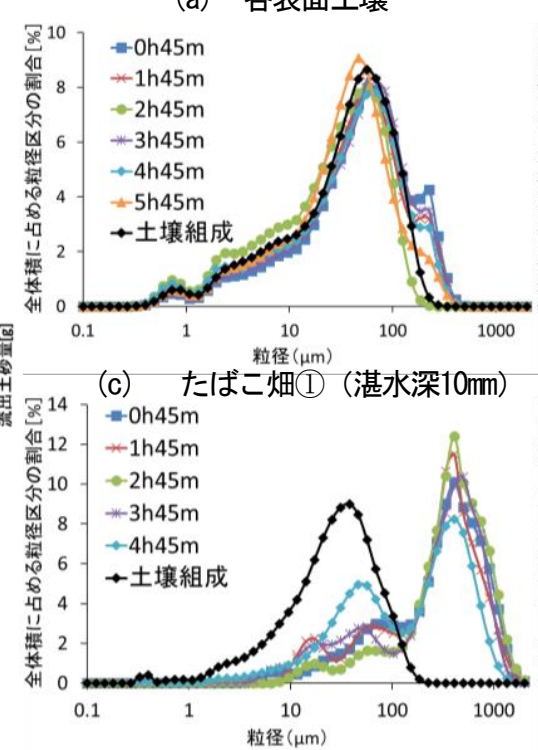

（e） 水田（湛水深 $3 \mathrm{~mm}$ )

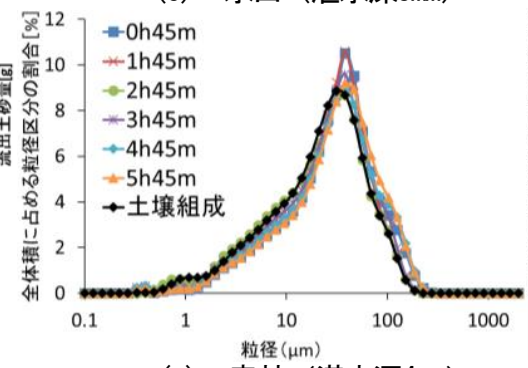

（g） 森林（湛水深 $4 \mathrm{~mm}$ )

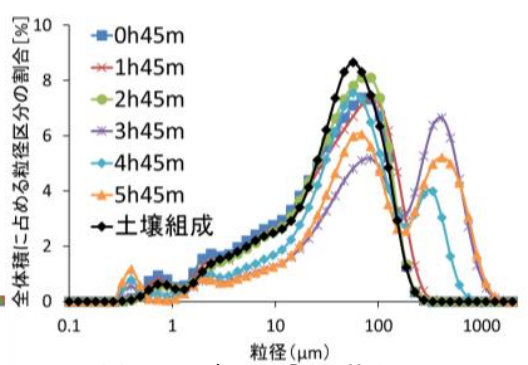

（b） たばこ畑(1)（湛水深 $7 \mathrm{~mm}$ )

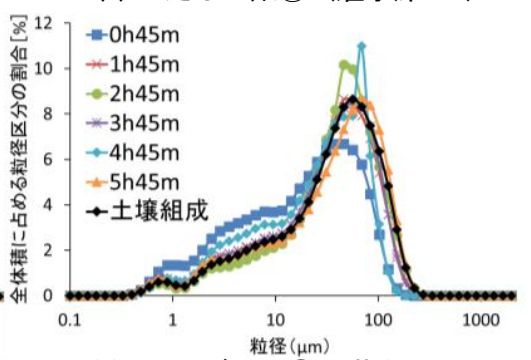

（d）たばこ畑(2) (湛水深 $3 \mathrm{~mm})$

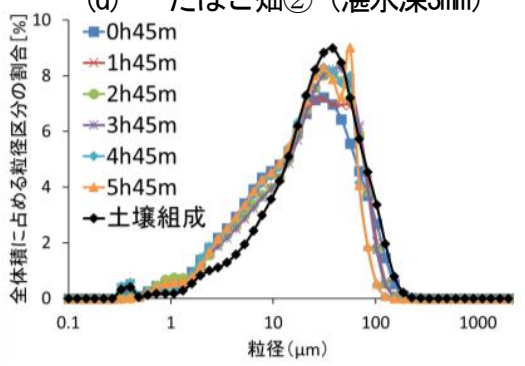

（f） 水田（湛水深20mm）

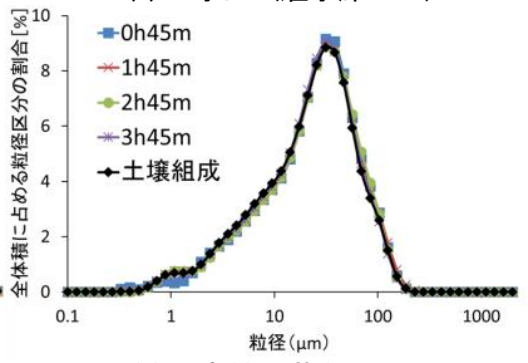

(h) 森林 (湛水深 $3 \mathrm{~mm})$

図-5 粒径分布の分析結果

水深20mmは初めから流出量が一定に近いが，これはこ の条件のみ湛水させた状態から実験を開始したためであ る.

$\mathrm{SS}$ 濃度はほとんどの実験条件で降雨の降り始めに高 く，時間の経過とともに減少していく傾向となった. 図 -4 (3) に示す森林の湛水深3mmの結果では，2時間を経 過したあたりから流出量が減少し, SS濃度が増加する 傾向となったが，湛水深が浅くなったことが考えられ， これは土壌内一水が浸透しやすくなる水道が形成されて しまい浸透量が増加した可能性がある.1時間経過した あたりから, 流出量がほぼ一定のため, 流出土砂量も $\mathrm{SS}$ 濃度同様に降雨の降り始めに高く, 時間の経過とと もに減少した。図-4(1)に示すたばこ畑(1)の湛水深7mm と湛水深 $10 \mathrm{~mm}$, 図-4(2) に示す水田の湛水深 $3 \mathrm{~mm}$ と湛 水深 $20 \mathrm{~mm} の \mathrm{SS}$ 濃度と流出土砂量の結果から，湛水深が 大きいほどSS濃度が低くなり, 侵食されにくくなるこ とが確認された。 これは，湛水によって土袞表面に与え
られる雨滴衝撃力が緩和され，雨滴の衝撃による侵食作 用が弱まったためだと考えられる。同様に，降雨の降り 始めにSS濃度が高濃度となるのも, 実験開始時は湛水 していないので，雨滴が直接土畩表面に当たり，より多 く侵食されたと考えられる。 また，実験開始時にSS濃 度が同じ值とならないのは，前の実験で大きく重たい粒 子がすでに侵食されていたり，侵食されやすい粒子が流 出してしまったりしたため, 1回目よりSS濃度が低く なったためだと考えられる.

浸透量は森林，たばこ畑，水田の順に多く，森林土畩 がたばこ畑や水田よりも浸透能力がかなり高い結果と なった. 本実験では森林については，40～50 mm/hほど の浸透能が確認できた。加藤ら7による人工降雨装置を 用いたヒノキ人工林内での浸透能の野外測定における 39.0 172.8mm/hの浸透能の範囲内の值となった.

\section{（2）土粒子の粒度分布}




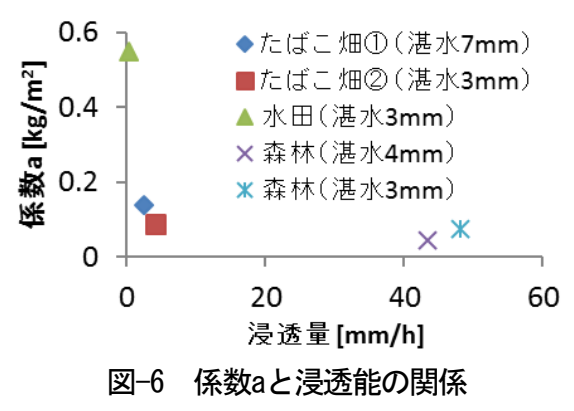

たばこ畑，水田，森林の土袞表面の土粒子の粒度分布 の結果と，それぞれの実験条件における流出土砂の粒度 分布の結果を前項の図-5 に示す，たばこ畑は水田と森 林に比心゙砂分が多い結果となった（図5-(a)）。図-5(b) に示すたばこ畑(1)の1回目と図-5(e)に示す水田の1回目 では，土壃表面に堆積していた枯れた植物片等の有機物 の影響があり，粒径が大きいものの割合が大きくなって いる. 1回目で有機物が洗い流され，2回目以降は粒径の 大きな有機物が流出しにくくなった可能性がある. 流出 土砂の粒径分布は土壌表面に存在する土粒子の粒径分布 と近い傾向がみられたことから, 流出土砂の粒径は土壤 表面に存在寸る土粒子の粒径に依存寸る事が示唆された

また，図-5(b) と図-5 (c) のたばこ畑(1)の湛水 $7 \mathrm{~mm}$ と 湛水 $10 \mathrm{~mm}$, 図-5 (e) と図-5(f) の水田の湛水 $3 \mathrm{~mm}$ と湛水 $20 \mathrm{~mm}$ のうに, 同じ土㙵で異なった湛水深を比較する と, 湛水が深くなると大きな粒子が侵食されにくくなる 結果がみられた。このことからも，湛水が土畩表面への 雨滴の衝撃力を緩和し, 湛水により粒径が大きくより大 きな輸送エネルギーを必要とする粒子の侵食が抑制され たと考えられる.

さらに詳細に結果を考察していくと，図-5(e)に示す 水田の湛水 $3 \mathrm{~mm}$ の結果では, 時間とともに大きな粒子 の割合が減少していく現象が見られ，土㙥表面が湛水し ていない初期の段階で，雨滴の衝撃によって大きな粒子 や有機物等が洗い流される可能性が示唆された。一方で, 図-5(g) に示寸森林の湛水深 $4 \mathrm{~mm}$ の場合，時間と共に大 きな粒子の割合が少し増加しているようにみえるが，こ れは，侵食されやすい小さな粒径の土粒子が先に流出し てしまったからである。また、図-5(b)に示すたばこ畑

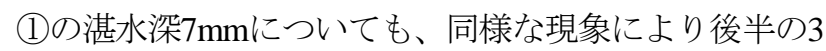
時間に大きな粒子の割合が増加したと考えられる。

\section{（3） 侵食モデルのパラメータの検討}

実験で得られた結果を用いて侵食モデルのパラメータ の検討を試みた．まず，Heiligらろ参考にし，より単純 化して侵食量を係数 $a\left(\mathrm{~kg} / \mathrm{m}^{2}\right)$ と降雨量で表現する方 法を，式(1)のように定義した.

$$
e_{s}=a P
$$

ここで， $e_{s}$ は雨滴の衝撃による侵食量 $(\mathrm{g} / \mathrm{s} / \mathrm{m}) ， P$ は 降雨量 $(\mathrm{m} / \mathrm{s})$ である. 今回の実験では, 降雨量 $P$ を一 定で与えているため, この係数 $a$ の時間変化は雨滴の

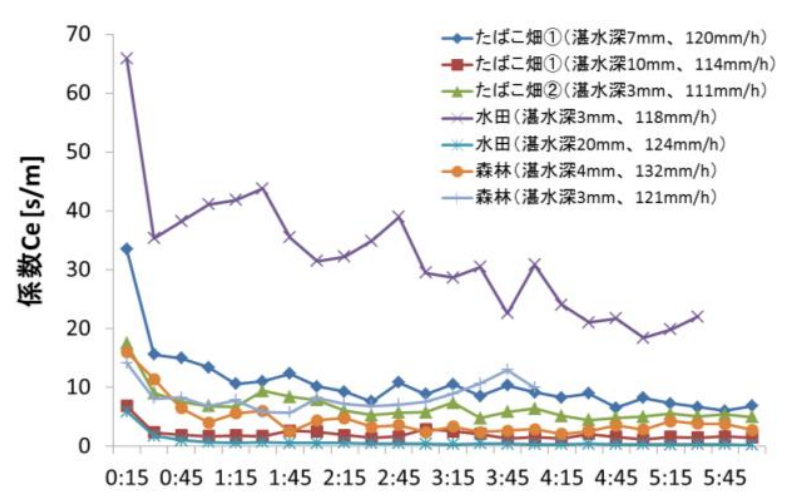

図-7 係数Ceの時間変化

衝撃による侵食量と似た結果となった，たばこ畑(1)，水 田，森林それぞれについて，同じ土㙥の異なる湛水深で 比較すると, 湛水深が深い方の係数 $a$ が小さくなる結 果となった.このことからも湛水深が大きくなると，湛 水によって雨滴衝撃力が緩和され，降雨量に対寸る侵食 量が少なるなることが示唆された. また, 係数 $a$ と浸 透能の大きさを比較した結果を図-6に示す，浸透能が高 い土袞ほど侵食されにくいことが考えられる。 それは, 同じ降雨量が供給されても浸透能が高ければ，地下へ浸 透していき, 表面流出の流出量が少なくなるため侵食さ れにくくなるためであると考えられる.このことから， 浸透能が影響する土壤表面からの流出量を考慮する必要 があるのではないかと考え，次に，Kinouchiら ${ }^{8}$ が口太 川流域内での放射性物質の移行を計算するモデル内で用 いている侵食モデルでの検討を行った.

湛水深の増加による雨滴侵食の低下を表す係数を $C e$ とし，式(2)のように定義した。

$$
\begin{aligned}
& e_{s}=C e B \rho_{s} R P \\
& C e=c_{f} \exp \left(-c_{h} h\right)
\end{aligned}
$$

ここで， $c_{f}$ は土壤や地表特性に関する定数 $(\mathrm{s} / \mathrm{m})$, $c h$ は湛水による雨滴侵食の減衰定数 $(1 / \mathrm{m}), h$ は湛 水深 $(\mathrm{m}), B$ は表面流の流水幅 $(\mathrm{m}), \rho_{s}$ は土粒子 密度 $\left(\mathrm{kg} / \mathrm{m}^{3}\right) ， R$ は流出高 $(\mathrm{m} / \mathrm{s})$ であり，土粒子密 度 $\rho_{s}$ の值は2700 $\mathrm{kg} / \mathrm{m}^{3}$, 流出幅 $B$ は実験容器の幅であ る $20 \mathrm{~cm}$ 用いた. 係数 $a$ と比較すると湛水の影響と流 出量が考慮されるモデルとなっている.

図-7に係数 $C e$ の時間変化を示す. 係数 $a$ の結果に比 べて流出高 $R$ を考慮しているため, 各実験条件におけ る值が近い值となった。浸透能の影響を流出高 $R$ で反 映することができていると考えられる.

また，同じ土䁃において2つの湛水条件で実験を行っ ているものの実験結果を用いて式(3)の係数 $c h$ を算出し た. 比較的流出量の安定している45分目〜2時間15分目 までの30分ごとの值を用いて計算した，その結果を図-8 に示す．土壌が異なることによる係数 $c_{h}$ の大きな差は 見られなかった. このことから，湛水による影響は土壤 


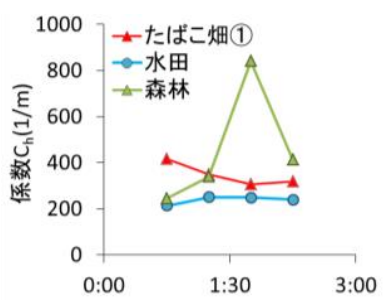

図-8 係数 $\mathrm{Ch}_{\mathrm{h}}$ の時間変化

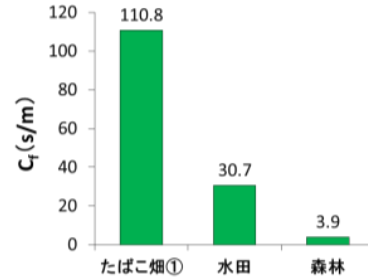

図-9 総量から求めた

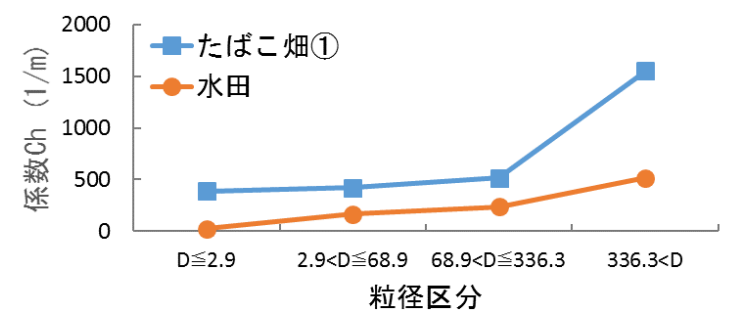

図-10 粒径区分別係数 $\mathrm{C}_{h}$

によって大きく違わない可能性がある.

しかし，図-10に示すように、粒径区分ごとに係数 $c h$ を 求めると，小さい粘土粒子よりも大きい砂の粒子の值の 方が大きくなる結果となり，大きい粒子の方が湛水の影 響を受けやすいことが示唆された.

また，流出土砂の6時間の総量の值を用いて, Kinouchiら ${ }^{8)}$ の浸食モデルを適用すると，土地利用ごと に係数 $c_{f}$ が求められた. 各土壌の係数 $c_{f}$ の結果を図 -9 に示す. その結果から, 土畩によって係数 $c_{f}$ の值が異 なるので，土壌による特性の違いは係数 $c_{f}$ によって表 現できると考えられた。このことから，Kinouchiら ${ }^{8) の ~}$ 既存の土壤侵食モデルを用いた方が，土地利用ごとの土 袞特性を表現できることが示唆された。

\section{5. 結論}

本研究では，自然な降雨を再現できる室内人工降雨装 置を用いて土壤侵食実験を行い，土壌侵食現象を定量的 に分析し，侵食モデルのパラメータの検討を行った. こ の結果から, 流出量は土壌が乾燥している初期は少ない が，時間と共に安定していくことが分かった。しかし， SS濃度と侵食量は時間とともに減少する傾向となった。 これは，時間とともに湛水深が増加して土壌表面に与え る雨滴衝撃力を緩和したためであると考えられた.

流出土砂の粒度分布に関しては，初期に有機物などの 大きな粒子が流れ出てくることが考えられ，たばこ畑， 水田, 森林いずれも1回目の実験において2回目の実験よ りも大きな粒子が確認された．また，湛水深が時間とと もに増加しているとみられる水田の湛水深 $3 \mathrm{~mm}$ の実験 では，最初に大きな粒子が多く，時間とともに減少する 傾向がみられ，湛水によって雨滴衝撃力が緩和されるこ とにより，大きな粒子の侵食量が減少したと考えられた。
一方で，森林の湛水深 $4 \mathrm{~mm}$ では，時間とともに粒径が 大きくなる傾向がみられた。 これは，小さい粒子が先に 洗い流され，相対的に大きい粒径の割合が増加したため であると考えられた。

実験結果をもとに，侵食モデルのパラメータの検討を 行った結果, 雨滴による侵食をモデルで表現するには, 降雨量だけを考慮する単純な方法では不十分であること が示唆された. 流出量, 湛水深だけでなく, 係数 $c_{f}$ に よって土袞の違いも考慮できるKinouchiら ${ }^{8)}$ の既存の侵 食モデルを適用寸ることが，土地利用による土壌特性の 違いを考慮した土壌侵食現象を表現するためには適して いることが示唆された．また，粒径区分ごとの特性の違 いは係数 $c h$ によって表現できる可能性が示唆された.

謝辞: 本研究は, 科研費 (新学術領域研究, 課題番号 25110503）により助成を受けて行われた。ここに記して 謝意を表する.

\section{参考文献}

1) 恩田裕一ほか: 放射性物質の包括的移行状況調查報告書, 国立研究開発法人日本原子力研究開発機構福島研究開発部 門, 2012.

2) Q. He, D. E. Walling: Interpreting particle size effects in the adsorption of ${ }^{137} \mathrm{Cs}$ and unsupported ${ }^{210} \mathrm{~Pb}$ by mineral soils and sediments, Journal of Environment Radioactivity, Vol.30 No.2, pp.117-137, 1996.

3) A. Heilig, D. DeBruyn, M.T. Walter, C.W. Rose, J.-Y. Parlange, T.S. Steenhuis, G.C. Sander, P.B. Hairsine, W.L. Hogarth, L.P. Walker: Testing a mechanistic soil erosion model with a simple experiment, Journal of Hydrology, 244, pp.9-16, 2001.

4) B.Gao, M.T. Walter, T.S. Steenhuis, J.-Y. Parlange, B.K. Richards, W.L. Hogarth, C.W. Rose: Investigating raindrop effects on transport of sediment and non-sorbed chemicals from soil to surface runoff, Journal of Hydrology, 308, pp.313-320, 2005

5) Majid Mahmoodabadi, Sara Arjmand Sajjadi: Effects of rain intensity, slope gradient and particle size distribution on the relative contributions of splash and wash loads to rain-induced erosion, Geomorphology, 253, pp.159-167, 2016

6) 西村拓, 中野政詩, 宮㟝毅 : 室内人工降雨装置による土壤 クラストの形成と浸食との関連性，農業土木学会論文集, 146, pp.101-107, 1990

7) 加藤弘亮, 恩田裕一, 伊藤俊, 南光一樹 : 振動ノズル式降 雨実験装置を用いた荒廃ヒノキ人工林における浸透能の野 外測定，水文・水資源学会誌，21(6)，pp.439-448，2008

8) T. Kinouchi, K. Yoshimura and T. Omata, Modeling radiocesium transport from a river catchment based on a physically-based distributed hydrological and sediment erosion model, Journal of Environment Radioactivity, DOI:10.1016/j.jenvrad.2014.07.022, p. $1-9,2014$.

(2015. 9. 30受付) 